\title{
In situ Raman characterization of minerals and degradation processes in a variety of cultural and geological heritage sites
}

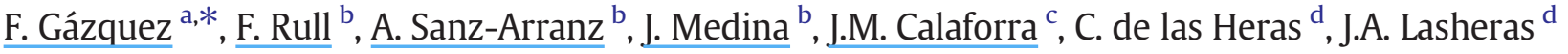 \\ a Department of Earth Sciences, University of Cambridge, Downing Street, Cambridge, Cambridgeshire CB2 3EQ United Kingdom \\ b Department of Condensed Matter Physics, Crystallography and Mineralogy, University of Valladolid, Paseo de Belén, 7, 47011 Valladolid, Spain \\ c Water Resources and Environmental Geology Research Group, University of Almería, Crta.Sacramento s/n, 04120, La Cañada de San Urbano, Almería, Spain \\ d Museo de Altamira, Ministerio de Educación, Cultura y Deportes, 39330 Santillana del Mar, Cantabria, Spain
}

\section{A R T I C L E I N F O}

\section{Article history:}

Received 20 September 2015

Received in revised form 8 January 2016

Accepted 12 April 2016

Available online xxxx

\section{Keywords:}

In situ Raman spectroscopy

Cultural heritage

Speleothems

Rock-art pigments

Burgos Cathedral

Altamira Cave

El Soplao Cave

Gruta de las Maravillas

\begin{abstract}
A B S T R A C T
We test the capabilities of in situ Raman spectroscopy for non-destructive analysis of degradation processes in invaluable masterpieces, as well as for the characterization of minerals and prehistoric rock-art in caves. To this end, we have studied the mechanism of decay suffered by the 15th-century limestone sculptures that decorate the retro-choir of Burgos Cathedral (N Spain). In situ Raman probe detected hydrated sulfate and nitrate minerals on the sculptures, which are responsible for the decay of the original limestone. In addition, in situ Raman analyses were performed on unique speleothems in El Soplao Cave (Cantabria, N Spain) and in the Gruta de las Maravillas (Aracena, SW Spain). Unusual cave minerals were detected in El Soplao Cave, such as hydromagnesite $\left(\mathrm{Mg}_{5}\left(\mathrm{CO}_{3}\right)_{4}(\mathrm{OH})_{2} \cdot 4 \mathrm{H}_{2} \mathrm{O}\right)$, as well as ferromanganese oxides in the black biogenic speleothems recently discovered in this cavern. In the Gruta de las Maravillas, gypsum $\left(\mathrm{CaSO}_{4} \cdot 2 \mathrm{H}_{2} \mathrm{O}\right)$ was identified for the first time, as part of the oldest cave materials, so providing additional evidence of hypogenic mechanisms that occurred in this cave during earlier stages of its formation. Finally, we present preliminary analyses of several cave paintings in the renowned "Polychrome Hall" of Altamira Cave (Cantabria, N. Spain). Hematite $\left(\mathrm{Fe}_{2} \mathrm{O}_{3}\right)$ is the most abundant mineral phase, which provides the characteristic ochre-reddish color to the Altamira bison and deer paintings. Thus, portable Raman spectroscopy is demonstrated to be an analytical technique compatible with preserving our cultural and natural heritage, since the analysis does not require physical contact between the Raman head and the analyzed items.
\end{abstract}

(c) 2016 Elsevier B.V. All rights reserved.

\section{Introduction}

In most cases, mineralogical investigations of cultural and geological items require an initial phase of mineral sampling, which may sometimes pose a threat to the preservation status of a protected heritage site. For instance, detailed mineralogical characterization of building materials has enabled the detection of the source of stone pathologies in a variety of historical buildings and masterpieces [1-6, among others]; however, the need for material sampling (in the order of grams) for subsequent destructive analysis in the laboratory can damage the masterpieces or other elements of interest.

Another example of potentially destructive sampling is given by mineralogical studies in protected caves, which are usually

\footnotetext{
* Corresponding author.
}

sites of significant aesthetic, geological and touristic relevance [7]. Oversampling and bad practice on the part of researchers during field work might produce severe damage in the caverns [8,9], in particular, to speleothems [10]. Remarkably, some caves host both relevant geological and archeological features that lead cave managers and authorities to maximize preservation measures. The restrictive policies for material sampling and the impossibility of remaining for long periods in these subterranean environments, due to visitor perturbations on microclimate [11], are in direct contrast with the need to characterize the composition and origin of the elements that are subject to protection.

In this context, portable, and non-invasive analytical techniques provide new opportunities for studying the mineralogical composition of delicate and precious materials, without the need for sample preparation. In the present study, we test the capabilities of a miniaturized Raman spectrometer for in situ non-destructive analysis of minerals in 
degraded limestone sculptures in Burgos Cathedral (N Spain) and in three Spanish caves that accommodate valuable speleothems and prehistoric rock-art. Raman analyses were utilized in each case to shed light on particular mineralogical issues and unanswered questions.

\section{Study sites}

\subsection{The retro-choir of Burgos Cathedral}

In situ Raman spectroscopy was used to perform a preliminary screening of the type of materials responsible for the decay of the 15th-century sculptures that decorate the retro-choir of Burgos Cathedral (N Spain). The retro-choir comprises five retables carved in limestone by the French sculptor and architect, Felipe Vigarny. Among them, the ones representing the Crucifixion of Christ and the Descent from the Cross are affected intensively by degradation mechanisms, including limestone disaggregation, flaking, peeling, and stone cracking (Fig. 1).

Burgos Cathedral was declared a World Heritage Site by UNESCO in 1984 (http://whc.unesco.org/en/list/316) and represents the top tourist attraction of the city of Burgos and of the Castile and Leon region, welcoming up to 350,000 visitors each year. In this case, preliminary in situ Raman analyses allowed for the selection of representative areas for subsequent sampling and further detailed laboratory analysis using other mineralogical techniques [6].

\subsection{El Soplao Cave}

El Soplao Cave was opened as a show cave in 2005 and receives up to 200,000 visitors each year. Spectacular helictites and huge speleothems are the most relevant aesthetic features of this mining show-cave [12]. Other unusual speleothems have also been described, including amberine stalactites [13], flowstones containing layers of cemented detrital materials [14], black ferromanganese crusts and stromatolites [15, 16], frostwork-type speleothems and moonmilk deposits [17], some of which were studied in our in situ survey.

\subsection{Gruta de las Maravillas}

The Gruta de las Maravillas (Cave of Wonders), located in the village of Aracena (Huelva, SW Spain) has been open to the public since 1914, and currently welcomes about 150,000 visitors every year. This cavern boasts a wide variety of speleothem types, including anthodites, subaqueous and subaerial flowstones and coralloids, cave raft cones and huge columns. In this study, we analyzed the mineralogical characteristics of rare bluish helictites in the Palmatoria sector of the cave. The presence of subaqueous speleothemic calcite crusts and erosive forms, such as cupolas and scallops (usually related to phreatic mechanisms)
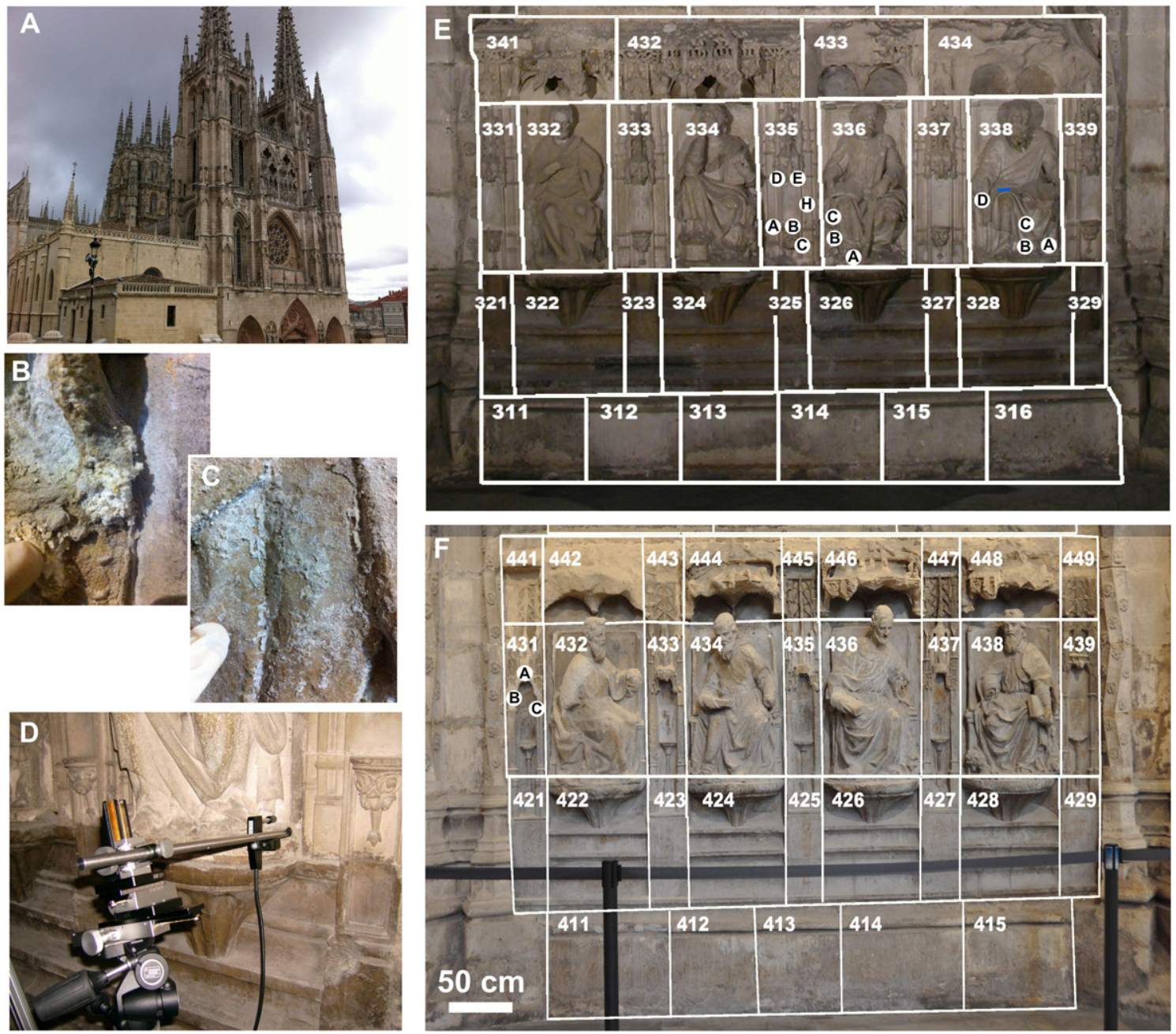

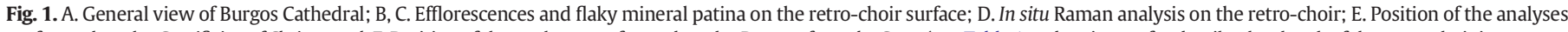

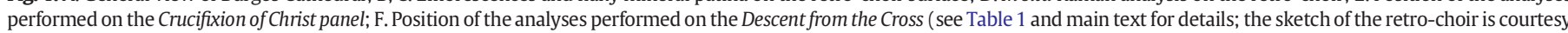
of Carlos Sanz). 
Table 1

Results of in situ Raman spectroscopy analyses performed in the retro-choir of Burgos Cathedral.

\begin{tabular}{|c|c|c|c|}
\hline Analyses ID & Location & Materials description & Raman signals $\left(\mathrm{cm}^{-1}\right)$ and mineral assignment \\
\hline $335 A$ & Quadrant 335 & Yellow powder on figure surface & Calcite $(1086,713,284,158)$, Niter (1050), Epsomite (986) \\
\hline 335B & Quadrant 335 & White powder on figure surface & Calcite $(1086,713,284,158)$, Niter (1050), Epsomite (986) \\
\hline $335 \mathrm{C}$ & Quadrant 335 & White powder on figure surface & Calcite $(1086,713,284,158)$, Niter (1050), Epsomite (986) \\
\hline $335 \mathrm{D}$ & Quadrant 335 & Efflorescence & Calcite $(1086,713,284,158)$, Niter (1050), Epsomite (986), Gypsum (1009), Anhydrite (1016) \\
\hline $335 \mathrm{E}$ & Quadrant 335 & Efflorescence & Calcite $(1086,713,284,158)$, Niter (1050), Epsomite (986) \\
\hline $335 \mathrm{~F}$ & Quadrant 335 & White patina & Calcite $(1086,713,284,158)$, Niter $(1050)$ \\
\hline 335G & Quadrant 335 & Original building material & Calcite $(1086,713,284,158)$ \\
\hline $336 \mathrm{~A}$ & Quadrant 336 & White powder on figure base & Calcite $(1086,713,284,158)$, Niter $(1050)$, Epsomite $(986)$, Sulfate $(1010,1016)$ \\
\hline 336B & Quadrant 336 & Efflorescence & Calcite $(1086,713,284,158)$, Niter (1050), Epsomite (986) \\
\hline $336 C$ & Quadrant 336 & White powder on figure surface & Calcite $(1086,713,284,158)$, Niter (1050), Epsomite (986) \\
\hline $338 \mathrm{~A}$ & Quadrant 338 & White powder on figure surface & Calcite $(1086,713,284,158)$, Niter $(1050)$ \\
\hline 338B & Quadrant 338 & White powder on figure surface & Calcite $(1086,713,284,158)$, Niter $(1050)$ \\
\hline $338 \mathrm{C}$ & Quadrant 338 & Original building material & Calcite $(1086,713,284,158)$ \\
\hline 338D & Quadrant 338 & Original building material & Calcite $(1086,713,284,158)$ \\
\hline $431 \mathrm{~A}$ & Quadrant 431 & Efflorescence & Niter (1050) \\
\hline 431B & Quadrant 431 & Efflorescence & Niter (1050) \\
\hline $431 \mathrm{C}$ & Quadrant 431 & Efflorescence & Niter (1050), Anhydrite (1016) \\
\hline
\end{tabular}

has been interpreted as evidence of subaqueous conditions that would have occurred in the earlier stages of formation of the cave [18]. Although it has been suggested that thermal-hypogenic mechanisms operated during these initial speleogenetic phases [18], no mineralogical or geochemical evidence has yet been found. To shed light on the cave origin, we used in situ Raman to analyze mineral crusts deposited on the marble bedrock that are vestiges of these earlier stages.

\subsection{Altamira Cave}

In situ Raman analysis of prehistoric rock-art (some 36,160$15,329 \mathrm{cal} \mathrm{BP}$ ) in the renowned "Polychromes Hall" of Altamira Cave (rated as the "Sistine Chapel" of the Paleolithic), were also performed, with the purpose of determining the mineralogical nature of the pigments used by the Paleolithic artists. This cave was declared World Heritage Site by the UNESCO in 1985 (http://whc.unesco.org/en/list/310) and was recently reopened to the public under an extremely restrictive visitor regime.

\section{Methodology and sampling strategies}

\subsection{In-situ Raman spectroscopy}

In situ Raman spectroscopy analyses were done at the sites described above during several surveys between 2012 and 2014. The Raman analyses were carried out using a BWTEK Raman device, composed of a BWTEK BRM-OEM-785 diode laser (785 nm), a BWTEK BAC100-785E Raman head, and a BWTEK Prime T BTC661E-785CUST spectrometer with a Hamamatsu CCD (S10141-1107S, 2048 pixels). The equipment covers a spectral range in Raman displacement of $150-3000 \mathrm{~cm}^{-1}$, with a spectral resolution of $5 \mathrm{~cm}^{-1}$ measured as FWHM. Spectra were acquired using commercial software provided by BWTEK. The maximum laser power was $270 \mathrm{~mW}(100 \%)$ but was adjusted to lower values using the BWTEK software. The laser was initially set at $10 \%(\sim 30 \mathrm{~mW})$ of its nominal power and was gradually increased up to $40-60 \%(\sim 100-160 \mathrm{~mW})$ in most analyses. Under these conditions, no thermal degradation of the materials was observed, which is normally evidenced by a drastic increase of the Raman spectrum baseline. The mean integration time ranged from 1 to $10 \mathrm{~s}$ and 20-50 accumulations were performed for each analysis. The Raman head was coupled with a photographic tripod adapted for analyses of vertical surfaces. In most cases, the analyses were done without the need for the Raman head to touch the materials to be analyzed.

Spectra treatment, including manual baseline correction, was performed using OPUS software. Mineralogical identification used a set of algorithms and a Raman spectra database that are being developed in

\section{EL SOPLAO CAVE}
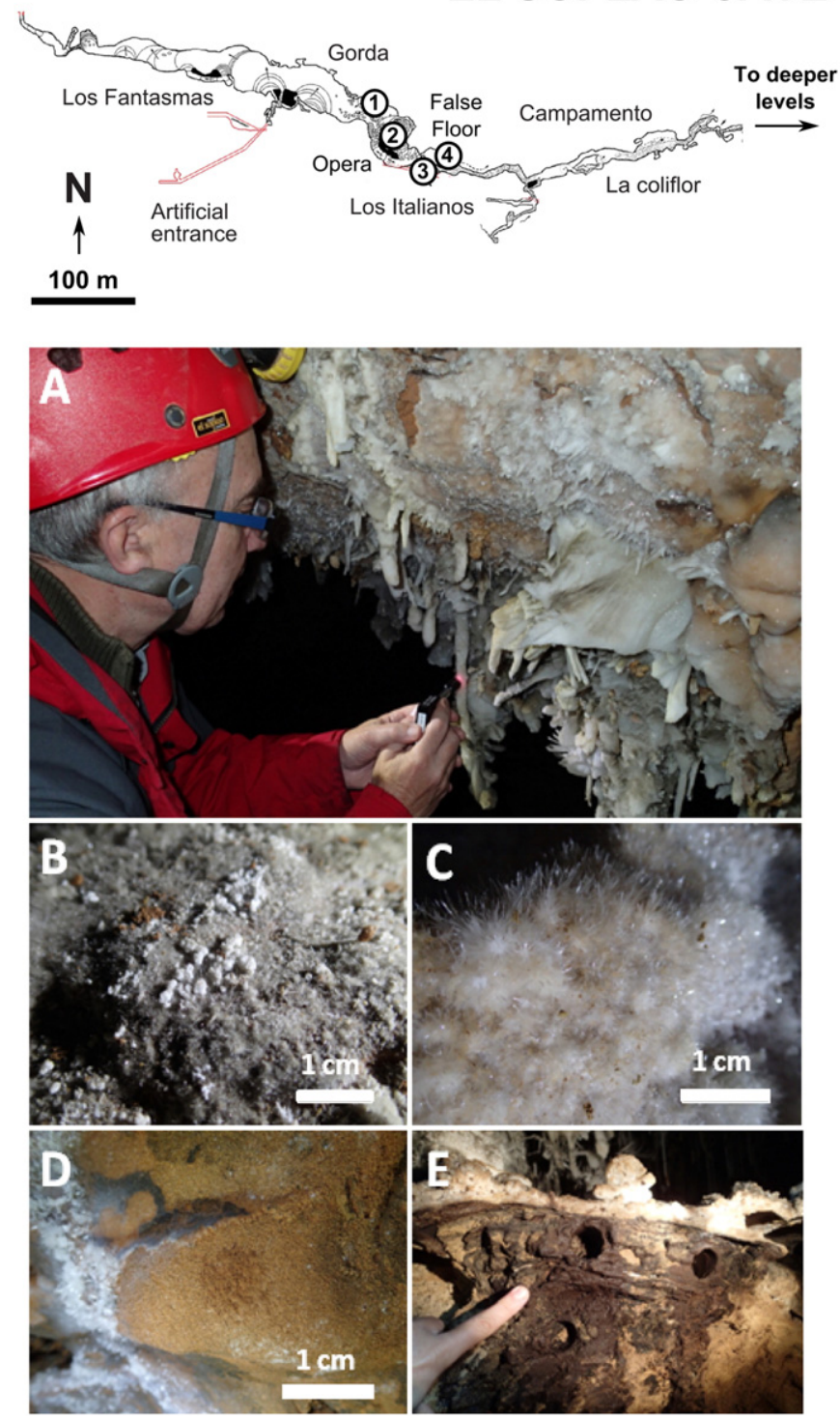

Fig. 2. Topography of El Soplao Cave and location of the study site. A. In situ Raman analysis of a stalactites; B. Moonmilk deposits; C. Frostwork speleothem; D. Alteration materials on the bedrock; E. Ferromanganese stromatolites. 
Table 2

Results of in situ Raman spectroscopy in El Soplao Cave.

\begin{tabular}{|c|c|c|c|}
\hline Analyses ID & Location & Materials description & Raman signals $\left(\mathrm{cm}^{-1}\right)$ and mineral assignment \\
\hline SPL-GOR-01 & Gorda gallery & Moonmilk & Hydromagnesite $(1117,724,753,244,266)$ \\
\hline SPL-GOR-02 & Gorda gallery & Frostwork & Aragonite $(1086,706,207)$ \\
\hline SPL-GOR-03 & Gorda gallery & Saccharide textured crystals & Aragonite $(1086,706,207)+$ Calcite $(1086,712,282)$ \\
\hline SPL-GOR-04 & Gorda gallery & Helictite & Aragonite $(1086,706,207)$ \\
\hline SPL-GOR-05 & Gorda gallery & Moonmilk & Aragonite $(1086,706,207)$ \\
\hline SPL-GOR-06 & Gorda gallery & Moonmilk & Aragonite $(1086,706,207)+$ Hydromagnesite $(1117,724,753)$ \\
\hline SPL-GOR-07 & Gorda gallery & Moonmilk & Aragonite $(1086,706,207)+$ Hydromagnesite $(1117,724,753)$ \\
\hline SPL-GOR-08 & Gorda gallery & Moonmilk & Aragonite $(1086,706,207)+$ Huntite $(1122,315,272)$ \\
\hline SPL-GOR-09 & Gorda gallery & Frostwork & Aragonite $(1086,706,207)$ \\
\hline SPL-GOR-10 & Gorda gallery & Alteration materials on bedrock & Dolomite $(1097,719,285)$ \\
\hline SPL-GOR-11 & Gorda gallery & Bedrock & Dolomite $(1097,719,285)$ \\
\hline SPL-OPE-01 & Opera hall & Helictite & Calcite $(1086,712,282)$ \\
\hline SPL-OPE-02 & Opera hall & Helictite & Calcite $(1086,712,282)+$ Aragonite $(1086,706,207)$ \\
\hline SPL-ITA-01 & Italianos gallery & Helictite & Aragonite $(1086,706,207)$ \\
\hline SPL-ITA-02 & Italianos gallery & Frostwork & Aragonite $(1086,706,207)$ \\
\hline SPL-ITA-03 & Italianos gallery & Frostwork & Aragonite $(1086,706,207)$ \\
\hline SPL-ITA-04 & Italianos gallery & Alteration materials on the bedrock & Calcite $(1086,712,282)+$ Oxides \\
\hline SPL-ITA-05 & Italianos gallery & Stalactite & Aragonite $(1086,706,207)+$ Calcite $(1086,712,282)$ \\
\hline SPL-ITA-06 & Italianos gallery & Stalactite & Aragonite $(1086,706,207)$ \\
\hline SPL-FAL-01 & False floor hall & Frostwork & Aragonite $(1086,706,207)$ \\
\hline SPL-FAL-02 & False floor hall & White stalactite & Aragonite $(1086,706,207)$ \\
\hline SPL-FAL-03 & False floor hall & Ferromanganese stromatolites & Birnessite $(576,680)$ \\
\hline SPL-FAL-04 & False floor hall & Ferromanganese stromatolites & Birnessite $(577,680)$, goethite $(546,475,391,295)$ \\
\hline SPL-FAL-05 & False floor hall & Ferromanganese stromatolites & Birnessite $(576,680)$ \\
\hline
\end{tabular}

the framework of the 2018 European Space Agency ExoMars mission [19]. Raman spectra were compared with the ExoMars Raman standard database, which currently comprises over 300 minerals [20], and the RRUFF mineralogical database (www.rruff.info [21]).

\subsection{The retro-choir of Burgos Cathedral}

A square sampling grid was established over the surface of each of the five retro-choir panels (each $9 \mathrm{~m}$ high and $5 \mathrm{~m}$ wide), giving 45 quadrants per panel and a total of over 250, covering a surface of $220 \mathrm{~m}^{2}$. The analyses in this study were conducted on the most deteriorated panels (the Crucifixion of Christ and the Descent from the Cross), especially in the lower and central parts of the panels (quadrants 335, 336, 338 in the Crucifixion of Christ and quadrant 441 in the Descent from the Cross). The location of each analysis is given in Fig. 1 and the mineralogical characterization in Table 1 . Seventeen in situ analyses were performed on different materials, including the apparently unaltered original limestone, as well as efflorescences and flaky patinas.

\subsection{El Soplao Cave}

Raman analyses in El Soplao Cave were focused on four study areas (Fig. 2): (1) Gorda Gallery (SOP-GOR; 11 analyses) where several analyses were carried out on the carbonate bedrock of the cave and its overlying alteration materials. In addition, soft globular efflorescences (moonmilk), millimetre-sized acicular aggregates (frostwork) and sugary-texture patina and ochre-color alteration crust on the bedrock, were analyzed (Table 2 and Fig. 2). (2) Opera Hall (SOP-OPE; 2 analyses): moonmilk aggregates and white helictites on the cave ceiling. (3) The Italianos Gallery (SOP-ITA; 6 analyses): frostwork and moonmilk, helictites, stalactites and the carbonate bedrock were studied. (4) False Floor Hall (SOP-FAL; 5 analyses): carbonate helictites and frostwork, as well as ferromanganese stromatolites were analyzed.

\subsection{Gruta de las Maravillas}

The Raman study in Gruta de las Maravillas focused on two sites (Table 3 and Fig. 3): (1) Palmatoria Sector (ARA-PAL; 7 analyses), where we analyzed bluish aragonite helictites, moonmilk aggregates and frostwork. (2) Hall of the Nudes (ARA-DES; 7 analyses), in which the marble bedrock, dark alteration crust, brownish laminated carbonate layer and whitish carbonate flowstones were analyzed (Fig. 3). The analyses were performed on a wall where these materials were exposed as a result of work to adapt the cave for tourism in the early 20th century.

Table 3

Results of in situ Raman spectroscopy in the Gruta de las Maravillas.

\begin{tabular}{|c|c|c|c|}
\hline Analyses ID & Location & Materials description & Raman signals $\left(\mathrm{cm}^{-1}\right)$ and mineral assignment \\
\hline ARA-PAL-01 & Palmatoria sector & Blue helictites & Aragonite $(1086,706,207)+$ Cuprite $(217)$ \\
\hline ARA-PAL-02 & Palmatoria sector & Blue helictites & Aragonite $(1086,706,207)+$ Cuprite $(217)$ \\
\hline ARA-PAL-03 & Palmatoria sector & White helictites & Aragonite $(1086,706,207)$ \\
\hline ARA-PAL-04 & Palmatoria sector & White helictites & Calcite $(1086,712,282)$ \\
\hline ARA-PAL-05 & Palmatoria sector & White helictites & Calcite $(1086,712,282)+$ Aragonite $(1086,706,207)$ \\
\hline ARA-PAL-06 & Palmatoria sector & Brownish boxwork & Calcite $(1086,712,282)+$ Quartz $(462)$ \\
\hline ARA-PAL-07 & Palmatoria sector & Moonmilk & Aragonite $(1086,706,207)$ \\
\hline ARA-DES-01 & Desnudos sector & Marble hostrock & Calcite $(1086,712,282)$ \\
\hline ARA-DES-02 & Desnudos sector & Alteration crust & Calcite $(1086,712,282)+$ Gypsum $(1137,1007,493,411)$ \\
\hline ARA-DES-03 & Desnudos sector & Alteration crust & Calcite $(1086,712,282)+$ Gypsum $(1007,493,411)$ \\
\hline ARA-DES-04 & Desnudos sector & Laminated dark flowstone & Calcite $(1086,712,282)$ \\
\hline ARA-DES-05 & Desnudos sector & Laminated dark flowstone & Calcite $(1086,712,282)$ \\
\hline ARA-DES-06 & Desnudos sector & White flowstone & Calcite $(1086,712,282)$ \\
\hline ARA-DES-07 & Desnudos sector & White flowstone & Calcite $(1086,712,282)$ \\
\hline
\end{tabular}


GRUTA DE LAS MARAVILLAS
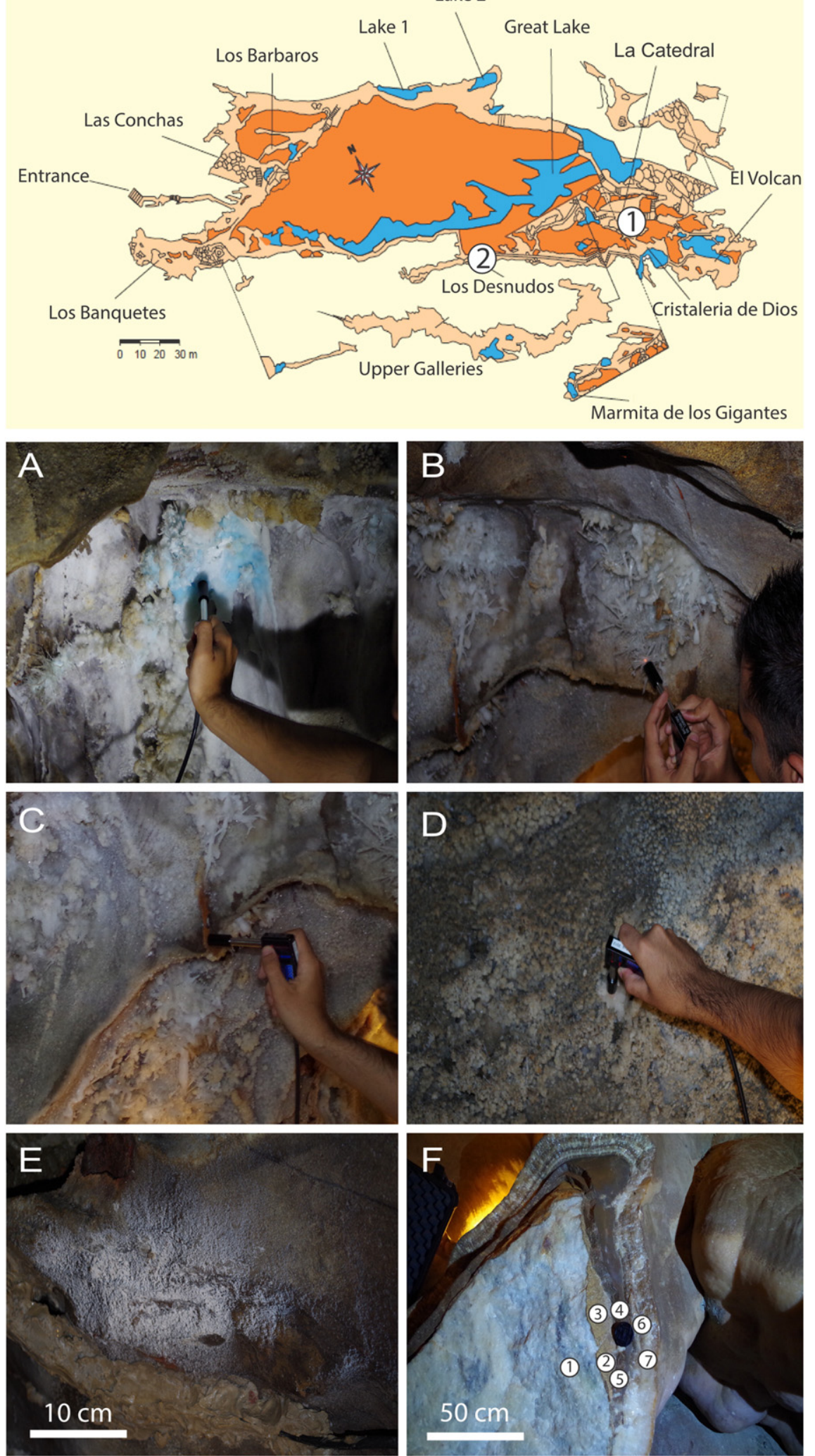

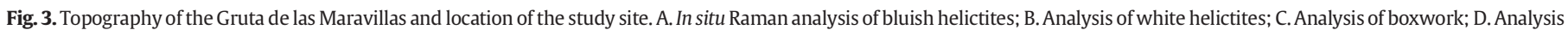
of carbonate concretions; E. Moonmilk deposits; F. Position for the analyses of the marble bedrock (1), alteration crusts (2, 3), a dark flowstone (4) and a white flowstone (5, 6$)$. 
Table 4

Results of in situ Raman spectroscopy of the rock-art paintings of the Polychrome Hall of Altamira Cave.

\begin{tabular}{|c|c|c|c|}
\hline Analyses ID & Figures & Material description & Raman signals $\left(\mathrm{cm}^{-1}\right)$ and mineral assignment \\
\hline ALT-01 & Extended bison & Reddish pigment (back) & Calcite $(1086,146)$ \\
\hline ALT-02 & Extended bison & Reddish pigment (body) & Calcite $(1086,146)+$ Hematites $(408,289)$ \\
\hline ALT-03 & Extended bison & Reddish pigment (body) & Calcite $(1086,146)+$ Hematites $(408,289,1300)$ \\
\hline ALT-04 & Extended bison & Black drawn (back) & Manganese oxides $(497,415)+$ gypsum? (1007) \\
\hline ALT-05 & Extended bison & Brownish pigments (leg) & 1089 (calcite) + Organic compounds $(1474,1412)$ \\
\hline ALT-06 & Extended bison & Brownish pigments (back) & Calcite $(1086,146)+$ Hematites $(408,289)+$ Hydromagnesite $(1121)$ \\
\hline ALT-07 & Hunched bison & Reddish pigment (body) & Hematites $(503,410,298)$ \\
\hline ALT-08 & Hunched bison & Reddish pigment (body) & Hematites $(503,410,298)$ \\
\hline ALT-09 & Extended bison & Reddish pigment (body) & Calcite $(1086,146)+$ Hematites $(408,289)$ \\
\hline ALT-10 & Great deer & Brownish pigments (leg) & Calcite $(1086,146)+$ Hematites $(408,289)$ \\
\hline ALT-11 & Great deer & Brownish pigments (leg) & Calcite $(1086,146)+$ Hematites $(408,289)$ \\
\hline ALT-12 & Claviform symbol & Reddish pigment & Calcite $(1086,146)+$ Hematites $(408,289)$ \\
\hline ALT-13 & Great deer & Brownish pigments (leg) & Calcite $(1086,146)+$ Hematites $(408,289)$ \\
\hline ALT-14 & Claviform symbol & Reddish pigment & Calcite $(1086,146)+$ Hematites $(408,289)$ \\
\hline
\end{tabular}

\subsection{Altamira Cave}

The Raman analyses in Altamira Cave addressed the mineralogical characterization of the pigments that compose certain rock-art features on the ceiling of the Polychrome Hall. This preliminary sampling was devoted to the analyses of deep reddish pigments and blackish traces of an extended bison ( 7 analyses) and a hunched bison ( 2 analyses). The brownish pigments of the great deer ( 3 analyses) and the reddish claviform symbols that appear on the legs of the great deer and the central part of the chamber ( 2 analyses) were also studied (Table 4 and Fig 4).

\section{Results and discussion}

\subsection{The retro-choir of Burgos Cathedral}

In situ Raman spectroscopy detected 5 different minerals on the surfaces of the 15th-century sculptures that decorate the retro-choir of the
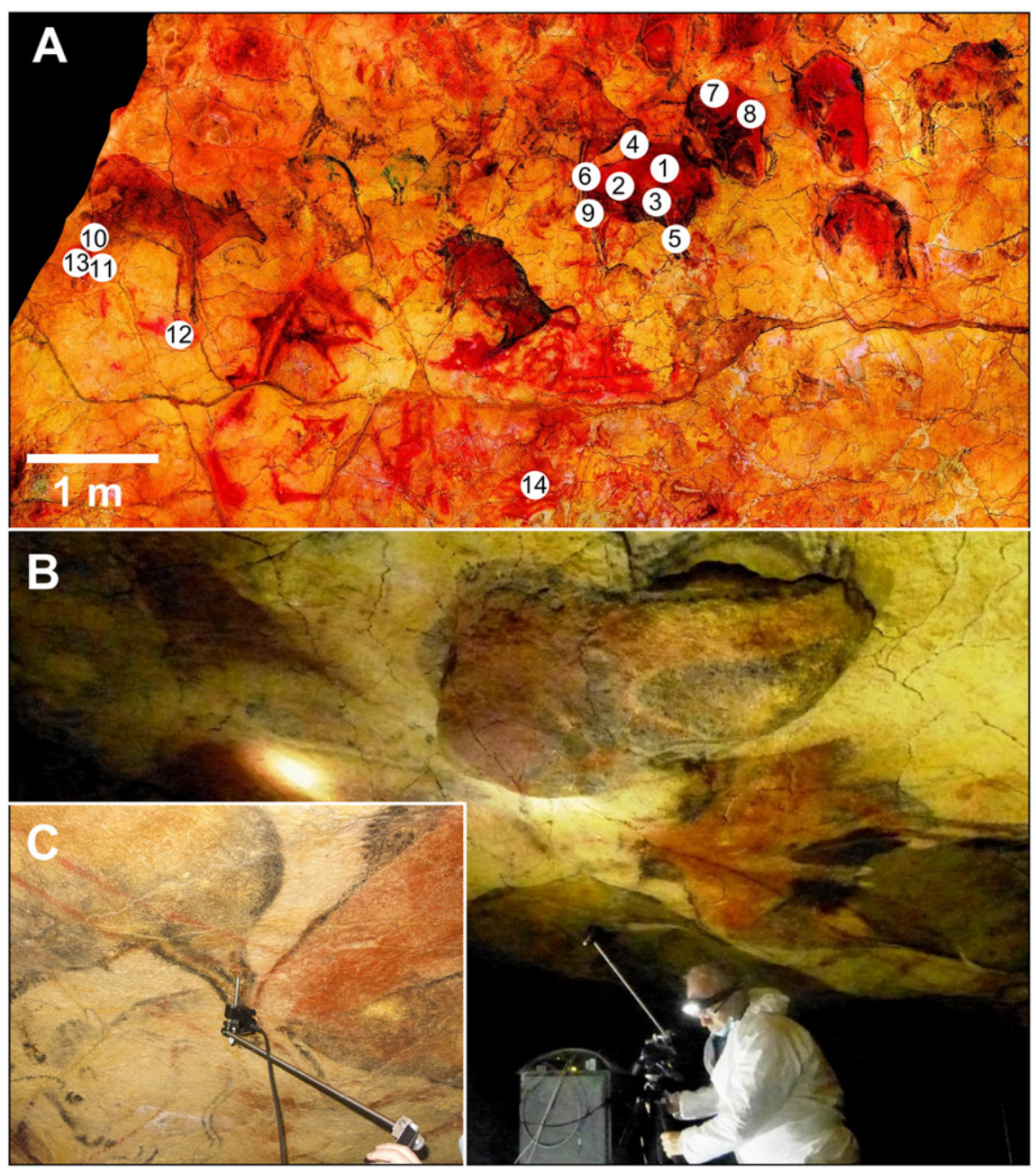

Fig. 4. A. Position for in situ Raman analysis in the ceiling of the Polychromes Hall of Altamira Cave. B, C. Details of analysis of the cave paintings. 
Burgos Cathedral (Fig. 5 and Table 1). Calcite $\left(\mathrm{CaCO}_{3}\right)$ was identified as the primary building material, from which the figure were carved, whereas niter $\left(\mathrm{KNO}_{3}\right)$, epsomite $\left(\mathrm{MgSO}_{4} \cdot 7 \mathrm{H}_{2} \mathrm{O}\right)$ and small amounts of gypsum $\left(\mathrm{CaSO}_{4} \cdot 2 \mathrm{H}_{2} \mathrm{O}\right)$ and anhydrite $\left(\mathrm{CaSO}_{4}\right)$ are present in the efflorescences and alteration patina (Fig. 1). These results are in close agreement with the results from the detailed mineralogical characterization of alteration materials in this masterpiece, carried out using diverse laboratory techniques (Raman and FT-Raman, X-ray diffraction and infrared spectroscopy) [6]. Though this thorough investigation flagged the presence of 20 different degradation compounds that are responsible for the decay of the original stone [6], Mg-sulphate (mainly epsomite) and K-nitrate (along with Na-nitrate) were found to be the most abundant detrimental materials and the main cause of stone disaggregation in the retro-choir. This decay process is attributed to the hydrationdehydration and dissolution-precipitation cycles of certain minerals, such as those in the epsomite-hexahydrite $\left(\mathrm{MgSO}_{4} \cdot 7 \mathrm{H}_{2} \mathrm{O} /\right.$ $\mathrm{MgSO}_{4} \cdot 6 \mathrm{H}_{2} \mathrm{O}$ ) system. The derived stress in the capillary network has been identified as one of the main cause of ageing of building materials $[22,23]$. In the case of Burgos Cathedral, the damage observed is connected to the capillary rise of salts-bearing water from the subsoil [6].

Remarkably, the in situ Raman survey in the retro-choir took approximately 6 h, whereas over 300 work hours were required for the laboratory analyses by different techniques of nearly 150 samples [6]. Taking into account that both methodologies produced similar results in terms of identifying the main problem affecting the limestone sculptures and mineralogical identification of the most abundant degradation compounds, the in situ Raman technique is demonstrated to be a fast and efficient tool for studying stone pathology without the need for material sampling or sample preparation, as also suggested in recent investigations [3,4,24, among others].

\subsection{El Soplao Cave}

The in situ Raman analyses in El Soplao Cave detected five different carbonate minerals, as well as metallic oxy-hydroxides (Fig. 6 and Table 2). Aragonite $\left(\mathrm{CaCO}_{3}\right)$ is the most common mineral forming part of the speleothems in this cavern, as revealed by the analysis of anthodites, stalactites and frostwork speleothems at the three study sites (Fig. 6). These results agree with the mineralogy of flowstones and frostwork speleothems reported in previous studies of this cave [12]. Aragonite is a rather common mineral in dolostone caves such as El Soplao, where the dolomitic nature of the bedrock has been corroborated by Raman spectroscopy. Dolomite $\left(\mathrm{CaMg}\left(\mathrm{CO}_{3}\right)_{2}\right)$ is the main constituent of the cave walls which, in places, display a brownish crust also composed of microcrystalline dolomite and calcite (Fig. 6). According to previous investigations $[25,26]$, the high $\mathrm{Mg}^{2+} / \mathrm{Ca}^{2+}$ ratio in the dripwater favors the precipitation of aragonite and inhibits the nucleation of calcite. This could explain the overwhelming presence of aragonite in El Soplao Cave.

On the other hand, hydromagnesite $\left(\mathrm{Mg}_{5}\left(\mathrm{CO}_{3}\right)_{4}(\mathrm{OH})_{2} \cdot 4 \mathrm{H}_{2} \mathrm{O}\right)$ has been detected as cottonball-like globular aggregates (moonmilk) on the cave walls (Fig. 6), frequently placed at the apex of aragonite acicules. In places, hydromagnesite is accompanied by aragonite and huntite $\left(\mathrm{Mg}_{3} \mathrm{Ca}\left(\mathrm{CO}_{3}\right)_{4}\right)$. Precipitation of $\mathrm{Mg}$-carbonates in caves has usually been attributed to the evaporation of Mg-rich solutions. In some cases, the presence of these minerals in caves is related to microbial activity, though this has not been confirmed for the moonmilk deposits of El Soplao Cave [17].

The dark laminated deposits of the False Floor Hall are composed of Fe-Mn oxides that in previous studies, were identified by XRD as goethite $(\alpha-\mathrm{FeO}(\mathrm{OH}))$ and birnessite $\left(\left[\mathrm{A}_{\mathrm{y}} \mathrm{MnO}_{2-\mathrm{y}} \cdot \mathrm{z}\left(\mathrm{H}_{2} \mathrm{O}\right)\right]\right.$ (where A represents an interlaminar cation). Indeed, the Raman signals at around 500 and $700 \mathrm{~cm}^{-1}$ (Fig. 6) can be assigned to birnessite, which is a rather common mineral in subterranean environments $[27,28]$. The precipitation of this metal oxide in the El Soplao Cave is related to the mobilization of manganese from the host rock probably under phreatic anaerobic conditions and subsequent precipitation on the walls and floors of the cave as oxides when the water table fell and conditions were again oxygenic [15]. The oxidation of manganese was probably mediated by microorganisms (as suggested by the presence of fossil bacteria inside ferromanganese speleothems discovered in this cave in previous studies [16]).

\subsection{Gruta de las Maravillas}

Aragonite and calcite were the most abundant minerals found by in situ Raman spectroscopy in the Gruta de las Maravillas. Both minerals form part of helictites, frostwork and flowstones in this cavity, with no clear spatial distribution or differentiation in terms of speleothem morphologies. Remarkably, the bluish aragonite anthodite of the Palmatoria Sector displays a weak Raman signal at $217 \mathrm{~cm}^{-1}$ that has been assigned to the minor presence of cuprite $\left(\mathrm{Cu}_{2} \mathrm{O}\right)$ (Fig. 7). This signal did not appear in spectra from other whitish speleothems at the same site. This finding is in accordance with earlier trace elements analyses of these speleothems in the Gruta de las Maravillas reported by Del Val et al. (1998) who found up to 183 ppm of copper to be present in these aragonite speleothems [29]. Despite being relatively rare, bluish aragonite speleothems have been described in several caves of Sardinia, Italy [30,31] and France [32]. Cabrol (1978) claimed that copper concentrations above 50 to $100 \mathrm{ppm}$ in aragonite might give rise to their bluish color.

At the same location in the cave, we analyzed boxwork-type features comprising calcite and quartz $\left(\mathrm{SiO}_{2}\right)$ (Fig. 3). The term "boxwork" refers to mineral veins in the bedrock which, due to the greater resistance of these infillings (usually calcite, quartz or metallic oxides), protrude from the cave wall after dissolution and/or corrosion of the surrounding host rock [33,34]. In the Gruta de las Maravillas, these veins represent a primitive subaqueous stage in which calcite and quartz precipitated in the cracks of the marble host rock. More recently, subsequent to the

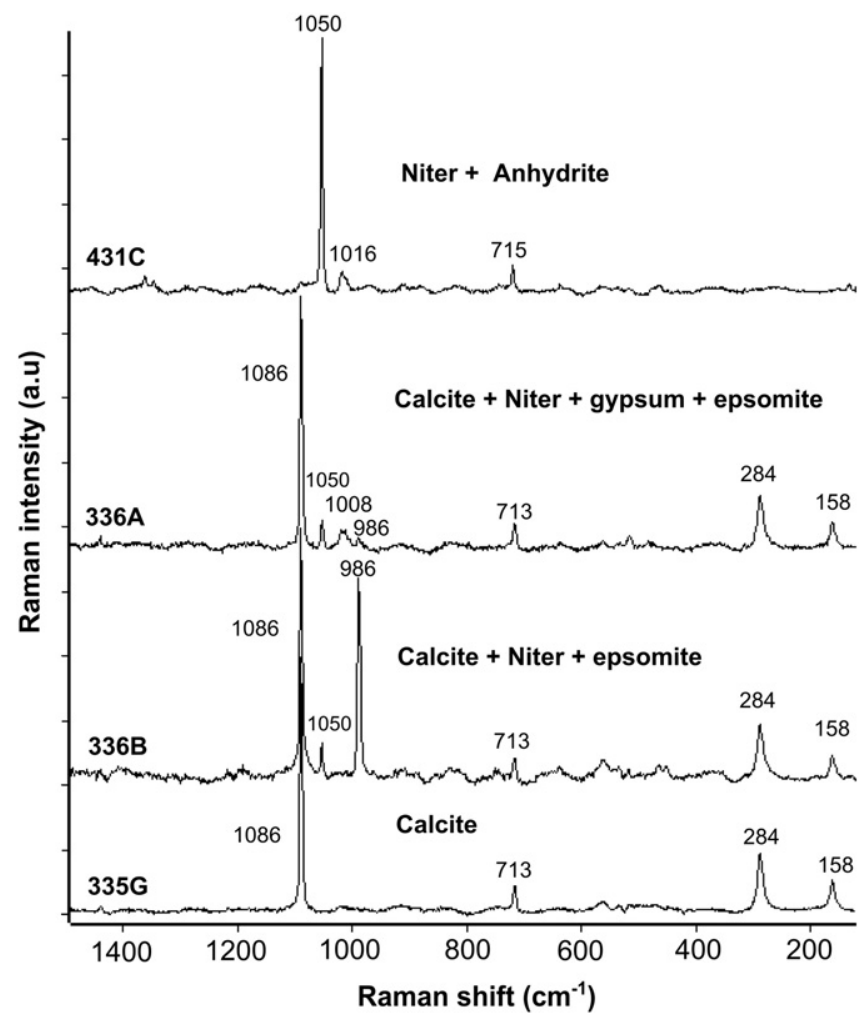

Fig. 5. Results of in situ Raman spectroscopy in the retro-choir of Burgos Cathedral. Different admixtures of hydrated sulfates and nitrate minerals were detected in efflorescences (431C and 436B) and other degradation compounds (436C), in addition to the original limestone. 


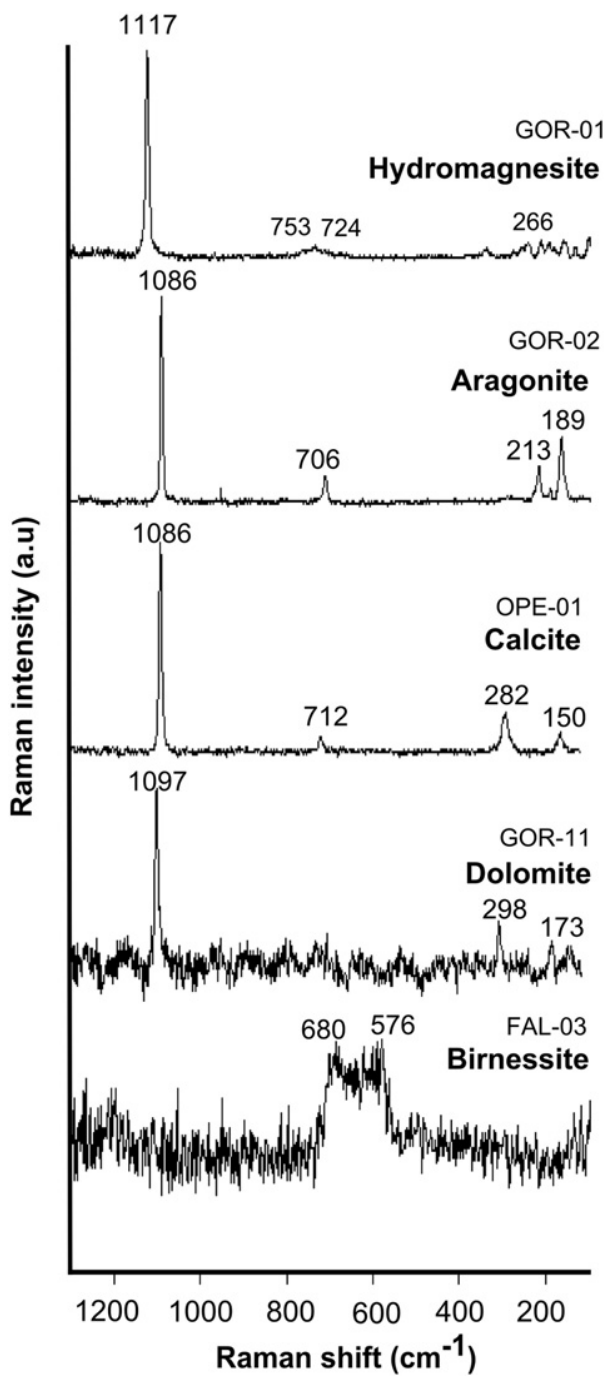

Fig. 6. Results of in situ Raman spectroscopy in El Soplao Cave. Different carbonate speleothems were analyzed (GOR-01, GOR-02, OPE-01), in addition to the dolostone bedrock. The ferromanganese stromatolites of the False Floor Chamber (FAL-03) were also studied.

speleogenetic mechanisms that produced the cave galleries and the fall of the water table to below the cave level, subaerial dissolutioncorrosion processes preferentially affected the carbonate host rock, which has a microcrystalline structure. In contrast, the veins of calcite and quartz were more resistant to corrosion and were less affected by erosion [34]. In this way, the calcite blades project into the cave in the form of a boxwork.

At the second study site in Gruta de las Maravillas, we analyzed the mineralogical sequence in the Hall of the Nudes, from the Precambrian marble bedrock to the more recent speleothemic calcite crusts (Fig. 3). All the phases showed a predominantly calcite composition, including the marble stone of the bedrock and the flowstones that later grew over the cave walls underwater, due to slow $\mathrm{CO}_{2}$-degassing and consequent supersaturation in calcite.

Remarkably, gypsum $\left(\mathrm{CaSO}_{4} \cdot 2 \mathrm{H}_{2} \mathrm{O}\right)$ has been detected, along with calcite, at the contact between the bedrock and the first of the laminated flowstone layers. This brownish lamina has a sugary texture and is a vestige of a primitive phase in the cave formation. The presence of gypsum at this stage unequivocally indicates that SAS (sulfuric acid speleogenesis) mechanisms were involved during the cavity formation, very probably in a thermal-water environment. Oxidation of pyrite $\left(\mathrm{FeS}_{2}\right)$, widely hosted in the Precambrian marble of the Aracena Massif [35], produced a lowering in the water $\mathrm{pH}$, which favored the corrosion of the marble and simultaneous precipitation of gypsum, following the reaction:

$4 \mathrm{FeS}_{2}+15 \mathrm{O}_{2}+18 \mathrm{H}_{2} \mathrm{O}+8 \mathrm{CaCO}_{3} \rightarrow 8 \mathrm{CaSO}_{4} \cdot 2 \mathrm{H}_{2} \mathrm{O}+4 \mathrm{FeOOH}+8 \mathrm{CO}_{2}$.

SAS has been proposed as being responsible for the genesis of dozens of caves worldwide [36-40], which in most cases also host gypsum deposits. Although iron oxyhydroxides are not detected by Raman in the points studied in the Gruta de las Maravillas, ocher-colored limonitetype substances $\left(\mathrm{FeO}(\mathrm{OH}) \cdot \mathrm{nH}_{2} \mathrm{O}\right)$ have been observed in many parts, infilling cracks in the bedrock; along with corrosion forms typical of hypogene speleogenesis. This suggests that the mechanism of pyrite oxidation and coupled gypsum/Fe-oxides precipitation described above took place during an earlier stage of development of this cave.

\subsection{Altamira Cave}

In situ analyses of the outstanding rock-art in the Polychromes Hall of Altamira Cave were performed for the first time using Raman spectroscopy. Hematite was the most common mineral utilized by the Paleolithic artists for the representations of bison, deer and claviform symbols on the chamber's ceiling (Fig. 8). The majority of the spectra flagged the presence of calcite, which could be attributed either to calcite Raman signals from the substrate limestone bedrock or to secondary calcite coatings more recently deposited on the ocher pigments, which has been used to date these paintings in recent studies [41].

In one of the spectra, we found a weak signal at $1121 \mathrm{~cm}^{-1}$. This has been attributed to the presence of hydromagnesite on the paintings (Table 4). This mineral was also detected in previous studies on moonmilk deposits in this cave, and pointed out as being a microbial mediated product, potentially detrimental to the conservation of the paintings [42]. It is worth noting that in some spectra we found several

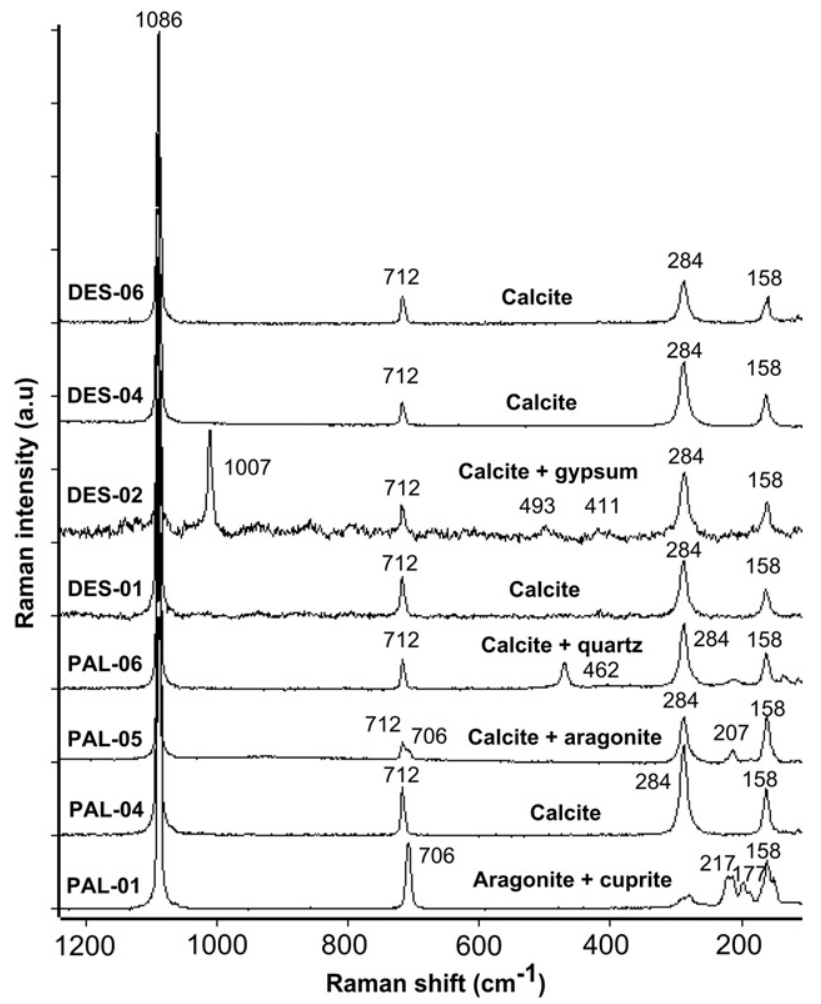

Fig. 7. Results of in situ Raman spectroscopy in the Gruta de las Maravillas. Helictites and carbonate concretions were analyzed in the Palmatoria Sector, showing the Raman spectra of calcite and aragonite (PAL-01, PAL-04, PAL-05, PAL-06). Note the presence of cuprite in the bluish aragonite helictites. The Raman signals observed in the spectra obtained from different materials in the Hall of the Nudes have been mainly assigned to calcite. Remarkably, gypsum has been detected at the contact between the marble bedrock and the first subaqueous speleothems. 


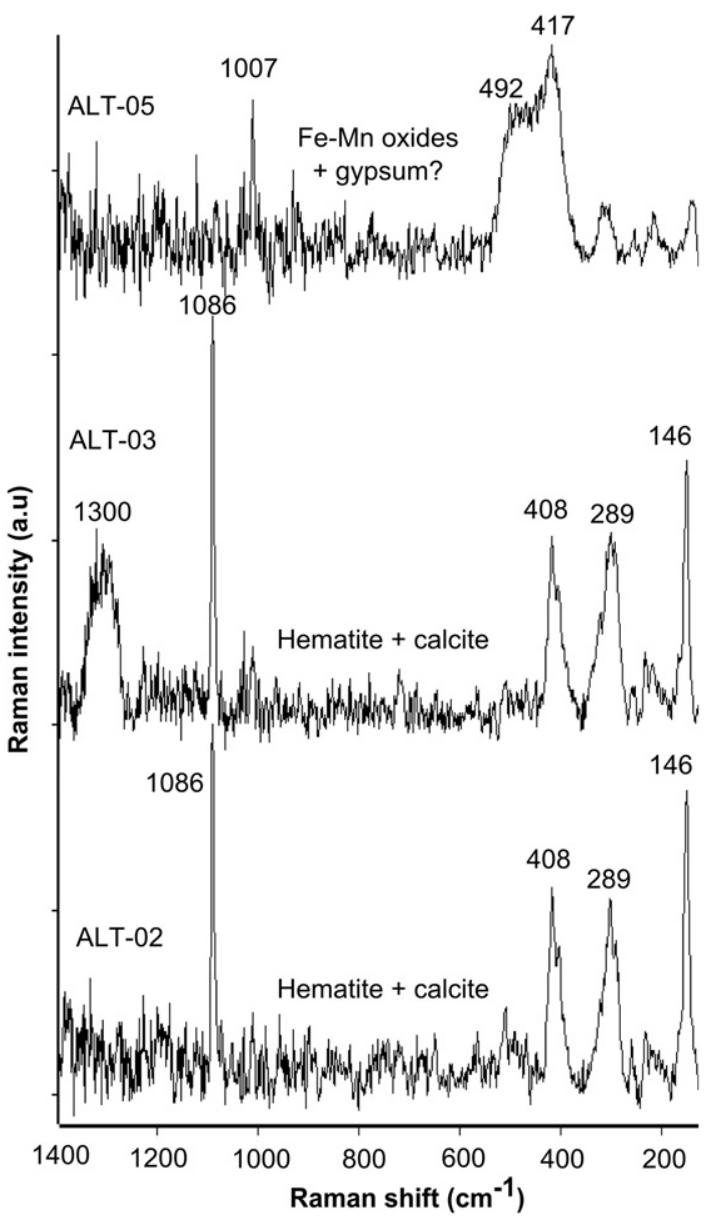

Fig. 8. Results of in situ Raman spectroscopy in the rock-art paintings of the Polychromes Hall of Altamira Cave. Hematite is the most common pigment in the paintings analyzed, in addition to calcite and manganese oxides.

sharp, weak signals at 1474 and $1412 \mathrm{~cm}^{-1}$ associated with calcite, which can be attributed to the presence of $\mathrm{Mg}$-oxalate or glushinskite $\left(\mathrm{Mg}\left(\mathrm{C}_{2} \mathrm{O}_{4}\right) \cdot 2\left(\mathrm{H}_{2} \mathrm{O}\right)\right)$ and $\mathrm{NH}_{4}^{+}$-oxalate or oxammite $\left(\left(\mathrm{NH}_{4}\right)_{2}\right.$ $\left.\left(\mathrm{C}_{2} \mathrm{O}_{4}\right) \cdot\left(\mathrm{H}_{2} \mathrm{O}\right)\right)$, which are typical metabolic intermediates and biomarkers of bacterial activity [43].

The black traces analyzed in this study showed the Raman spectra of metallic oxides, probably poorly crystalline manganese oxy-hydroxides (Fig. 8), also utilized in other Paleolithic art-rocks (i.e. in Lascaux and Ekain Caves [44]) as pigments for blackish features.

The great abundance of hematite in these figures matches the results from previous laboratory analyses of these paintings performed by Martín (1977) [45]. This author found mainly hematite in the ocher-colored drawings and $\mathrm{MnO} / \mathrm{Mn}_{2} \mathrm{O}_{3}$ in the blackish lines, as well as a lesser presence of carbonaceous compounds attributed to the use of charcoal as pigment. Likewise, this mineralogy roughly agrees with the results from the analysis of pigments and pictorial tools of the Altamira site stored in the collection of the Altamira Museum - that were initially analyzed using XRD by Cabrera (1980) [46], and more recently using Raman spectroscopy, XRD and FTIR by Rull et al. (2014) [47].

\section{Conclusions}

In situ Raman spectroscopy has enabled non-destructive mineralogical characterization of materials in deteriorated areas of the Burgos Cathedral's retro-choir and in three Spanish caves of geological and prehistoric/historical relevance. The in situ survey in Burgos Cathedral detected a variety of hydrated sulfate and nitrate minerals on the limestone figures, which are responsible for the decay of the limestone sculptures. The mineralogical analysis by in situ Raman spectroscopy in El Soplao Cave and the Gruta de las Maravillas found a variety of different minerals, including anhydrous and hydrated carbonates, as well as metallic oxides. In the case of the Gruta de las Maravillas, gypsum was detected for the first time. Its presence at the contact between the marble bedrock and the first speleothemic materials suggest that the initial cave stages were linked with SAS (sulphuric acid speleogenesis), which had been previously proposed for the origin of this cavity, but not until now demonstrated by empirical data. Finally, we found that hematite $\left(\mathrm{Fe}_{2} \mathrm{O}_{3}\right)$ is the most abundant mineral phase in the rock-art of the Polychromes Hall of Altamira Cave.

Our results from a variety of examples demonstrate that Raman is a non-destructive technique suitable for the analysis of minerals in the field, without the need for material sampling or sample preparation. Thus, it is compatible with the conservation of sites that are protected due to their cultural and/or geological value. In summary, Raman spectroscopy is confirmed as an alternative methodology to the traditional sampling and gathering of material for the study of minerals and degradation mechanisms affecting our cultural heritage, as well as for investigations of geological processes in caves.

\section{Acknowledgments}

Financial support for this study was provided by the Banco Santander Foundation, through project VA373A12-1, granted by the Regional Government of Castille and Leon, the funds of the Water Resources and Environmental Geology Research Group (University of Almería) and the Project "RLS Exomars Science" (AYA2011-30,291-C02-02; funded by the Ministry of Science and Innovation, Spain and EU FEDER funds). The authors are grateful to the incumbents of Burgos Cathedral for providing access to the temple during sampling, and to the managers of El Soplao S.L. for providing access to El Soplao Cave and allowing us to use their facilities. Wenceslao Martinez-Rosales is acknowledged for his help during sampling in the Gruta de las Maravillas. Our special thanks to Carlos Sanz for his kind permission to use his photograph.

\section{References}

[1] O. Buj, J. Gisbert, B. Franco, N. Mateo, B. Bauluz, J. Geol, Soc. London 331 (2010) 195-202.

[2] A. Duran, M.D. Robador, J.L. Perez-Rodriguez, Int. J. Archit Herit. 6 (3) (2011) 342-358.

[3] J. Dewanckele, M.A. Boone, T. De Kock, W. De Boever, L. Brabant, M.N. Boone, G. Fronteau, J. Dils, L. Van Hoorebeke, P. Jacobs, V. Cnudde, Sci. Total Environ. 447 (2013) 403-414

[4] O. Gómez-Laserna, M.A. Olazabal, H. Morillas, N. Prieto-Taboada, I. MartinezArkarazo, G. Arana, J.M. Madariaga, J. Raman Spectrosc. 44 (2013) 1277-1284.

[5] M. Veneranda, M. Irazola, M. Diez, A. Iturregui, J. Aramendia, K. Castro, J.M. Madariaga, J. Raman, Spectroscopy 45 (2014) 1110-1118.

[6] F. Gázquez, F. Rull, J. Medina, A. Sanz-Arraz, C. Sanz, Environ. Sci. Pollut. Res. 22 (2015) 15677-15689.

[7] A. Cigna, E. Burri, Development, management and economy of show caves, Int. J. Speleol. 29 (2000) 1-27.

[8] S.A. Truebe, J.E. Cole, M. Lee, H.R. Barnett, Proceedings, National Cave and Karst Management Symposium, Midway, Utah, 2011 149-153.

[9] S.A. Truebe, 20th National Cave and Karst Management Symposium, 2013 47-50.

[10] G.S. Springer, NSS News, June 2012 12-14.

[11] A. Fernández-Cortés, J.M. Calaforra, F. Sánchez-Martos, J. Gisbert, Int. J. Climatol. 26 (2006) 691-706.

[12] F. Gázquez, A. Delgado-Huertas, P. Forti, H. Stöll, J.M. Calaforra, J.J. Durán, F. Carrasco, in: Cuevas: Patrimonio (Ed.), Asociación de Cuevas turísticas, Naturaleza, Cultura y turismo, Madrid 2010, pp. 293-304.

[13] F. Gázquez, J.M. Calaforra, F. Rull, P. Forti, A. García-Casco, Int. J. Speleol. 41 (1) (2012) 113-123.

[14] F. Gázquez, J.M. Calaforra, P. Forti, H. Stoll, B. Ghaleb, A. Delgado-Huertas, Earth Surf. Process. Landf. 39 (10) (2014) 1345-1353.

[15] F. Gázquez, J.M. Calaforra, P. Forti, Int. J. Speleol. 40 (2) (2011) 163-169.

[16] C. Rossi, R.P. Lozano, N. Isanta, J. Hellstrom, Geology 38 (2010) 1119-1122.

[17] F. Gázquez, J.M. Calaforra, L. Sanna, Las cuevas turísticas como activos económicos: conservación e innovación, in: y J.J. Durán, P.A. Robledo (Eds.),Asociación Española de Cuevas Turísticas 2012, pp. 47-60.

[18] W. Martinez-Rosales, M. Lopez-Chicano, J.M. Calaforra, S.E. Laurizten, F. Saez, Rodriguez, El Karst de Andalucía, Geoespeleología, Bioespeleología y Presencia 
Humana, Calaforra, J.M and Berraocal J.A. Consejería de Medio Ambiente de la Junta de Andalucía, Sevilla 2008, pp. 209-215.

[19] I. Hermosilla, G. Lopez-Reyes, A. Catalá, A. Sanz, D.R. Llanos, F. Rull, EPSC Abstracts, 72012 EPSC2012-567-1.

[20] A. Sansano, R. Navarro, A.J.A. Manrique, J. Medina, I. Hermosilla, F. Rull, 45th Lunar and Planetary Science Conference, 2014 \#2803.

[21] R.T. Downs, Program and Abstracts of the 19th General Meeting of the International Mineralogical Association in Kobe, Japan, 2006 003-13.

[22] E. Ruiz-Agudo, F. Mess, P. Jacobs, C. Rodriguez-Navarro, Environ. Geol. 52 (2007) 269-281.

[23] M. Steiger, K. Linnow, Cryst. Growth Des. 8 (2008) 336-343.

[24] P. Colomban, J. Raman Spectrosc. 43 (2012) 1529-1535.

[25] J.L. Bischoff, W.S. Fyfe, Am. J. Sci. 266 (1968) 65-79.

[26] E.A. Burton, L.M., Walter, Geology 15 (1987) 111-114.

[27] A.Z. Miller, A. Dionísio, M.A. Sequeira-Braga, M. Hernández-Mariné, M.J. Afonso, V.S.F. Muralha, L.K. Herrera, J. Raabe, A. Fernández-Cortés, S. Cuezva, B. Hermosin, S. Sanchez-Moral, H. Chaminé, C. Saiz-Jimenez, Chem. Geol. 222-223 (2012) 181-191.

[28] F. Gázquez, J.M. Calaforra, P. Forti, J. De Waele, L. Sanna, F. Rull, A. Sanz, Geomorphology 198 (2013) 133-146.

[29] J. Del Vall, J.J. Duran, F. Ramirez, in: y J. J. Durán, J. López Martínez (Eds.), Karst en Andalucía, Instituto Tecnológico Geominero de España 1998, pp. 183-187.

[30] R. Cervellati, P. Forti, R. Zavatti, Speleologia Emiliana, 23 (17) (1971) 43-60.

[31] G.A. Caddeo, J. De Waele, F. Frau, L.B. Railsback, Int. J. Speleol. 40 (2) (2011) $181-190$
[32] P. Cabrol, Mémoires Recherches Géologiques Hydrogéologiques, 12, Université Montpellier, 1978275 p.

[33] C. Hill, P. Forti, Cave Minerals of the World, National Speleological Society, Huntsville, AL, $1997433 \mathrm{pp}$

[34] F. Gázquez, J.M. Calaforra, F. Rull, Geomorphology 177-178 (2012) 158-166.

[35] R. Piña, R. Lunar, L. Ortega, F. Gervilla, Revista Sociedad Española de Mineralogía, 112009 153-154.

[36] S. Galdenzi, T. Maruoka, J. Caves Karst, Stuifmail 65 (2003) 111-125.

[37] A.S. Engel, L.A. Stern, P.C. Bennet, Geology 32 (2004) 369-372.

[38] J.M. Calaforra, J. DeWaele, Geomorphology 134 (2011) 43-48.

[39] P. Forti, Z, Geomorphology 54 (2010) (2010) 115-135.

[40] Ph. Audra, F. Gázquez, F. Rull, J.-Y. Bigot, H. Camus, Geomorphology 249 (2015) 25-34.

[41] A.W.G. Pike, D.L. Hoffmann, M. García-Idez, P.B. Pettitt, Alcolea, R.D. Balbín, C. Gónzalez-Saiz, C. De las Heras, J.A. Lasheras, R. Montes, J. Zilhao, Science 336 (6087) (2012) 1409-1413.

[42] J.C. Cañaveras, S. Sanchez-Moral, E. Sanz-Rubio, J. Bedoya, V. Soler, I. Groth, Schumann P., L. Laiz, I. Gonzalez, C. Saiz-Jimenez, Geomicrobiol J. 16 (1999) 9-25.

[43] R.L. Frost, Anal. Chim. Acta 517 (1-2) (2014) 207-214.

[44] E. Chalmil, M. Menu, C. Vignaud, Meas. Sci. Technol. 14 (9) (2003) 1590.

[45] J. Martin, Informe sobre los estudios realizados en la cueva de Altamira, Instituo de Catalisis y Petroleoquimica del CSIC, Madrid, 1977.

[46] J.M. Cabrera, Altamira Symposium, Ministerio de Cultura, Madrid, 1980 621-641.

[47] F. Rull, F. Gázquez, J. Medina, A. Sanz, C. De las Heras, A. Prada, J.A. Lasheras, J.M. Calaforra, Revista Sociedad Española de Mineralogía, 192014 (in press). 